\title{
Biliary Cystadenoma Causing Obstructive Jaundice: Case Report and Literature Review
}

\author{
Noor Jawad ${ }^{a}$ Adam K. Woolf ${ }^{b}$ Jo-Anne Chin-Aleong ${ }^{b}$ \\ Ralph Greaves $^{\mathrm{a}}$ Hemant M. Kocher ${ }^{\mathrm{b}}$ \\ aDepartment of Gastroenterology, Whipp's Cross University Hospital, and \\ bBarts and the London HPB Centre, Royal London Hospital, London, UK
}

\author{
Key Words \\ Hepatectomy · Cyst · Liver
}

\begin{abstract}
Biliary cystadenomas are rare, potentially malignant neoplasms of biliary origin. Presentation is usually with vague and non-specific symptoms. Here, we describe an unusual case of biliary cystadenoma in a woman presenting with acute onset obstructive jaundice and review the relevant literature of 26 such cases reported over the last two decades.
\end{abstract}

\section{Case Report}

A 40-year-old, previously fit, Asian woman presented with obstructive jaundice. There was no significant history except for recent travel to Pakistan. Physical examination was normal apart from features of obstructive jaundice. Liver function tests revealed elevated serum alkaline phosphatase (419 IU/l), alanine transaminase (253 IU/l) and bilirubin $(50 \mu \mathrm{mol} / \mathrm{l})$. Hepatitis and hydatid serology were negative. Abdominal ultrasound (US) showed a $7 \mathrm{~cm}$ diameter cystic lesion in the region of the porta hepatis with an irregular echo pattern and dilatation of the left hepatic duct. Magnetic resonance cholangiopancreatography (MRCP) and CT confirmed a septate cystic lesion situated close to the porta hepatis (fig. 1, fig. 2); wall calcification or enhancement was not observed. Subsequent endoscopic retrograde cholangiopancreatography (ERCP) delineated a stricturing, filling defect at the junction of left and main hepatic ducts, corresponding to the area seen on cross-sectional imaging. Biliary brushings were negative and biliary stenting unsuccessful, prompting surgical exploration after discussion at the multi-disciplinary meeting. A left hepatectomy was performed and a polypoid mass lesion contiguous with the main hepatic cystic lesion was seen entering the main hepatic duct from the left hepatic duct. The left hepatic duct was transected at the confluence and the rest of the biliary tree was confirmed as normal by choledochoscopy prior to its closure. Gross pathological examination of the specimen revealed a thick walled cyst obstructing the left hepatic duct (ig. 3 ), and histology confirmed a biliary cystadenoma. Follow-up for 1 year after was uneventful.

Literature search using free text search 'biliary cystadenoma' and 'obstructive jaundice' along with related article search function and hand-searches of retrieved articles found 26 similar cases published 
over 24 articles from 1984 to 2008 . In this article we review the clinical course of the patients described in the last 3 years (2006-2008).

\section{Discussion}

Biliary cystadenomas are rare, potentially malignant neoplasms of biliary origin occurring predominantly in middle-aged women [1]; the first description of their resection was by William Williams Keen in the 1890s [2]. Biliary cystadenomas are composed of communicating, variable sized locules usually containing clear fluid. The locules are lined by simple, predominantly columnar epithelium resembling biliary epithelium with cytoplasmic mucin. Typically, there is cellular mesenchymal tissue resembling ovarian stroma. The epithelium may show varying degrees of dysplasia. High grade dysplasia or invasive carcinoma suggest transformation to cystadenocarcinoma [1]. The cyst size at presentation is usually between 5 and $15 \mathrm{~cm}$, its expansion causing vague, non-specific upper abdominal symptoms, such as mass, sometimes mimicking biliary calculous pain or gastroduodenal (acid-peptic) symptoms such as nausea [3-12]. Jaundice is an infrequently observed clinical feature caused by obstruction of biliary flow, usually transient and due to direct external compression of the biliary tree. Usually no direct communication exists between the cyst and the biliary tree although occasionally cases investigated with ERCP have demonstrated cyst filling [5]. Rarely, progressive or intermittent jaundice may be observed, as noted in our case, due to polypoid extension into the bile duct causing ball-valve obstruction, without evidence of invasion in a benign lesion. Previous reports of biliary cystadenoma presenting with obstructive jaundice are summarized in table 1.

In the past, ultrasound has been reported to be at least as sensitive as CT at demonstrating septa, when taken in the context of the history to suggest cystadenoma or cystadenocarcinoma [10]. CT supplies further information that helps differentiate these two diagnoses by revealing any protruding nodules, significant wall enhancement or calcifications, typical of malignant cystadenocarcinoma [10]. Recent reports have inferred advantages of biopsy or aspiration from cysts in the hope of identifying malignant change preoperatively [7]. Routine use cannot be advised due to risks of carcinomatosis, cyst rupture and the high probability of missing areas demonstrating atypia due to septation [5]. Interestingly, cystadenocarcinoma is encountered more commonly in men (than cystadenoma) resulting in only a slight propensity for women [11]. Additionally presentation is apparently later in life at a mean age of 10 years after that of cystadenoma [11]. Weight loss and symptoms of metastases may contribute to the clinical picture. Fortunately the ratio of cystadenocarcinomas to cystadenomas is low.

Hepatic cysts are noted in 1-5\% of the general population, with the most common pathologies being simple cysts, cystic necrosis of tumours, hydatid cysts, choledochal cysts, biliary cystadenoma amongst others. Simple hepatic cyst is extremely common, incidentally noted in $18 \%$ of patients investigated for unrelated pathologies [12]. Patients are managed by marsupialization, usually laparoscopic, only when symptomatic to achieve a more lasting cure as opposed to simple percutaneous aspiration. A hydatid cyst caused by the tapeworm Echinococcus granulosus or Echinococcus multilocularis is suspected when synchronous cysts are found (in $75 \%$ of infections) in addition to findings of eosinophilia and frequently with a history of inhabitation in an endemic area. CT findings of these and some less common differentials are provided in table 2.

Histological examination is required before a definitive diagnosis can be made. Factors such as bleeding within a benign locule, especially after attempted manipulation, can 
cause confusion with cystadenocarcinoma at imaging. Optimum management of cystadenomas involves either hepatectomy or, at the very least, enucleation. For a fully resected cystadenoma prognosis is excellent, recurrence being uncommon [9]. Where resection is subtotal for anatomical (biliary or vascular) reasons, it is recommended patients are followed up at least yearly for the first 2 years as recurrence is said to be most likely during this period [13]. Rare pathological variants may include serous type, which may regress spontaneously. Dysplasia or neoplasia may involve only part of the cyst wall [14].

\section{Conclusions}

(1) Cystic lesions of the liver may pose a diagnostic dilemma. Simple cysts are by far the most common lesions encountered. (2) Needle aspiration is not recommend for preoperative diagnosis. (3) Imaging in conjunction with a good history is usually sufficient to distinguish cystic hepatic lesions. (4) Jaundice can occur even in benign lesions, without signs of invasion, due to direct compression or ball-valve obstruction of the biliary tree by the cyst.

Table 1. Previous reports of biliary cystadenoma presenting with obstructive jaundice

\begin{tabular}{|c|c|c|c|c|}
\hline Reference & $\begin{array}{l}\text { Demographics } \\
\text { (No; age; sex) }\end{array}$ & Radiology & Management & Follow-up \\
\hline This report & $1 ; 40 ; \mathrm{F}$ & $\begin{array}{l}\text { US, CT, ERCP, } \\
\text { MRCP }\end{array}$ & left hepatectomy & 12 months \\
\hline Gonzalez [3] & $1 ; 32 ; \mathrm{F}$ & $\begin{array}{l}\text { US, CT, MRI, } \\
\text { MRCP }\end{array}$ & $\begin{array}{l}\text { left lateral segmen- } \\
\text { tectomy }\end{array}$ & unspecified \\
\hline Baudin [4] & $1 ; 40 ; \mathrm{F}$ & US, MRI, MRCP & left hepatectomy & 6 months \\
\hline Van Steenbergen [5] & $2 ; 46,40 ; \mathrm{F}$ & US, CT, ERCP & left hepatectomy & 19-103 months \\
\hline Nunes [6] & $1 ; 28 ; \mathrm{F}$ & US, CT, ERCP & left hepatectomy & unspecified \\
\hline $\mathrm{Yu}[7]$ & $1 ; 58 ; \mathrm{M}$ & $\begin{array}{l}\text { US, ERCP, MRI, } \\
\text { MRCP }\end{array}$ & left lobectomy & unspecified \\
\hline Seidel [8] & $1 ; 43 ; \mathrm{F}$ & $\begin{array}{l}\text { US, ERCP, MRI, } \\
\text { MRCP }\end{array}$ & $\begin{array}{l}\text { left lateral segmen- } \\
\text { tectomy }\end{array}$ & unspecified \\
\hline Delis [9] & $1 ; 50 ; \mathrm{F}$ & US, CT, ERCP & right hepatectomy & 18 months \\
\hline
\end{tabular}


Table 2. CT findings for differentials of hepatic cystadenoma [adapted from 11, 15]

\begin{tabular}{lll}
\hline Tumour & CT finding & Age group \\
\hline Cystadenoma & $\begin{array}{l}\text { septated multi-locular mass; regular with } \\
\text { no gross nodules; no intracystic mass }\end{array}$ & middle-aged women \\
\hline Cystadenocarcinoma & $\begin{array}{l}\text { irregular wall enhancement; septal } \\
\text { calcifications; pedunculated outgrowths; } \\
\text { intracystic masses }\end{array}$ & $\begin{array}{l}\text { men or women in } \\
\text { late life }\end{array}$ \\
\hline Simple hepatic cyst & $\begin{array}{l}\text { round, regular and unilocular; no } \\
\text { enhancement }\end{array}$ & $\begin{array}{l}\text { any, accumulate with } \\
\text { age }\end{array}$ \\
\hline $\begin{array}{l}\text { Hydatid cyst } \\
\text { wall calcifications; hypodense inner } \\
\text { matrix; rim enhancement with contrast; } \\
\text { multiple in 75\% }\end{array}$ & any \\
\hline $\begin{array}{l}\text { Caroli disease } \\
\text { central dot sign; communicates with }\end{array}$ & young adults \\
\hline $\begin{array}{l}\text { Undifferentiated } \\
\text { sarcoma }\end{array}$ & septated mass; irregular enhancement & children \\
\hline $\begin{array}{l}\text { Hepatocellular } \\
\text { carcinoma }\end{array}$ & $\begin{array}{l}\text { larger solid component; mosaic pattern; } \\
\text { venous invasion }\end{array}$ & $\begin{array}{l}\text { usually secondary to } \\
\text { risk factors }\end{array}$ \\
\hline
\end{tabular}

Fig. 1. Representative CT scan image with cyst in liver segment IV (arrow) along with left hepatic duct dilatation (arrowhead).

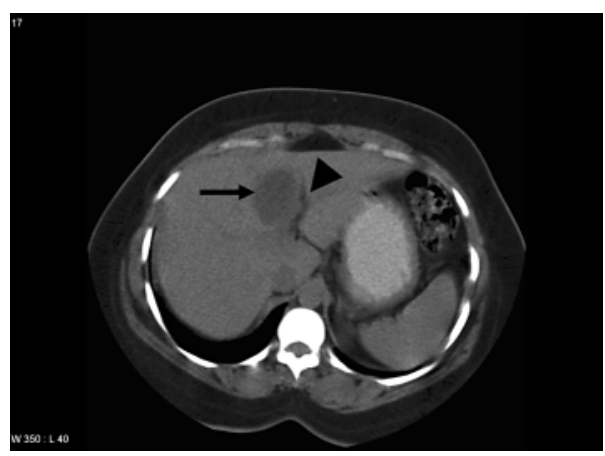




\begin{tabular}{r|l|l|l} 
Case Reports in & $\begin{array}{l}\text { Case Rep Gastroenterol 2009;3:269-274 } \\
\text { D0I: 10.1159/000226254 }\end{array}$ & Published online: September 12, 2009 & $\begin{array}{l}\text { O 2009 S. Karger AG, Basel } \\
\text { ISSN 1662-0631 } \\
\text { www.karger.com/crg }\end{array}$ \\
\hline
\end{tabular}

Fig. 2. MRCP showing cyst (arrow) and compression of the bile duct at the confluence (arrowhead).

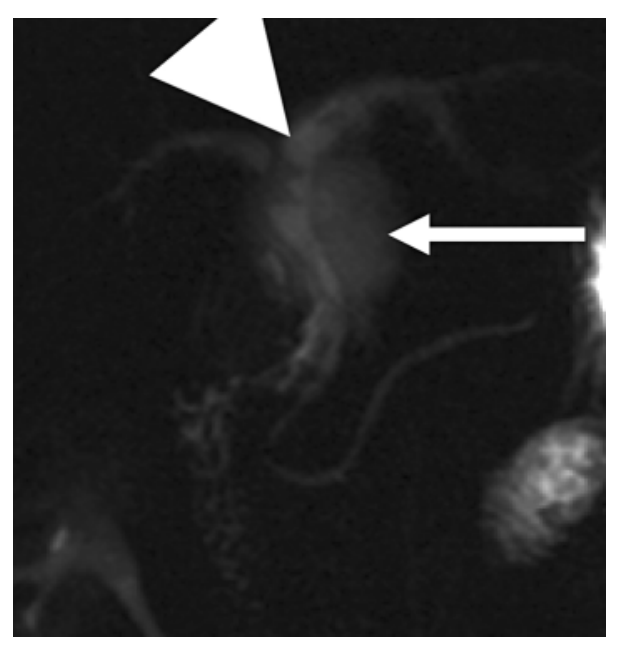

Fig. 3. Gross surgical specimen of left hepatectomy and histology slide showing ball-valve obstruction of the left hepatic duct (arrow) caused by the protrusive element of the biliary cystadenoma.
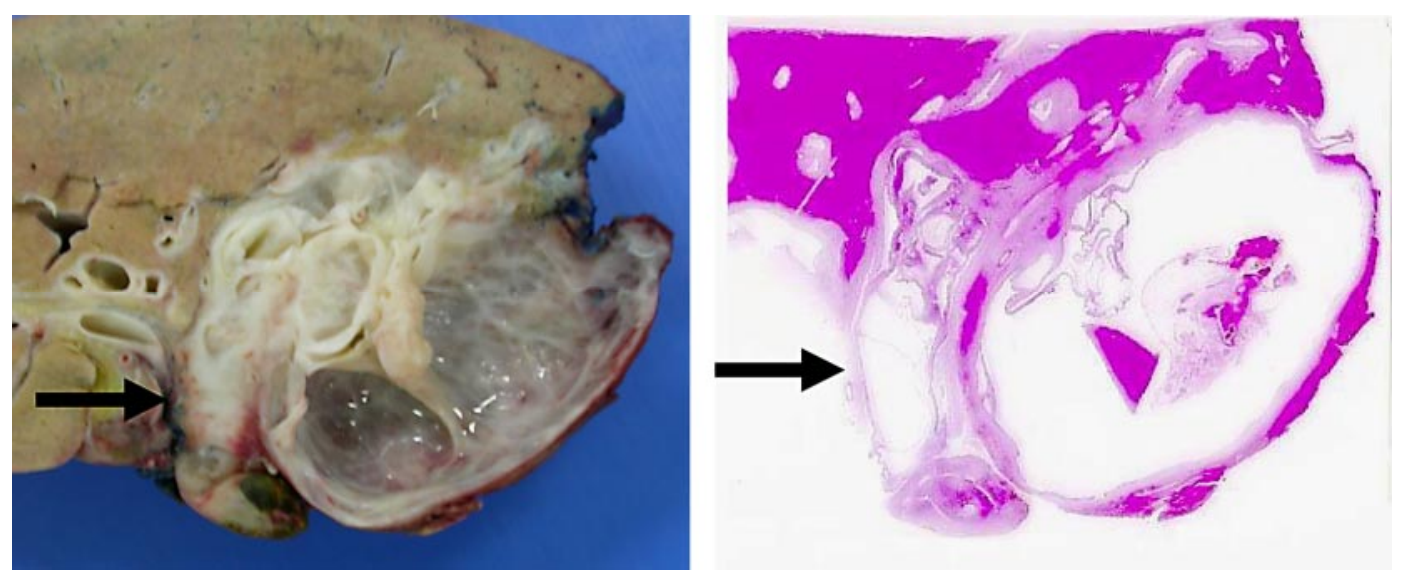


\section{References}

1 Kakar S, Burgart LJ: Tumours of the biliary system. Curr Diagn Pathol 2005;11:34-43.

2 Keen WW: Report of a case of resection of the liver for the removal of a neoplasm, with a table of seventy-six cases of resection of the liver for hepatic tumors. Ann Surg 1899;30:267-283.

-3 Gonzalez M, Majno P, Terraz S, Morel P, Rubbia-Brandt L, Mentha G: Biliary cystadenoma revealed by obstructive jaundice. Dig Liver Dis 2009;41:e11-e13.

-4 Baudin G, Novellas S, Buratti MS, Saint-Paul MC, Chevallier P, Gugenheim J, Bruneton JN: Atypical MRI features of a biliary cystadenoma revealed by jaundice. Clin Imaging 2006;30:413-415.

-5 Van Steenbergen W, Ponette E, Marchal G, Vanneste A, Geboes K, Van Rijkel JP, Fevery J, De Groote J: Obstructive jaundice due to hepatobiliary cystadenoma or cystadenocarcinoma. World J Gastroenterol 2006;12:5735-5738.

6 Nunes QM, Wight ND, Aithal GP, Dunn WK, Kaye PV, Lobo DN: Concurrent mucinous cystadenoma of the liver and bile duct: a rare cause of jaundice. Gastrointest Endosc 2006;63:870-872.

7 Yu FC, Chen JH, Yang KC, Wu CC, Chou YY: Hepatobiliary cystadenoma: a report of two cases. J Gastrointestin Liver Dis 2008;17:203-206.

-8 Seidel R, Weinrich M, Pistorius G, Fries P, Schneider G: Biliary cystadenoma of the left intrahepatic duct. Eur Radiol 2007;17:1380-1383.

-9 Delis SG, Touloumis Z, Bakoyiannis A, Tassopoulos N, Paraskeva K, Athanassiou K, Safioleas M, Dervenis C: Intrahepatic biliary cystadenoma: a need for radical resection. Eur J Gastroenterol Hepatol 2008;20:10-14.

- 10 Pojchamarnwiputh S, Na Chiangmai W, Chotirosniramit A, Lertprasertsuke N: Computed tomography of biliary cystadenoma and biliary cystadenocarcinoma. Singapore Med J 2008;49:392-396.

$\checkmark 11$ Läuffer JM, Baer HU, Maurer CA, Stoupis C, Zimmerman A, Büchler MW: Biliary cystadenocarcinoma of the liver: the need for complete resection. Eur J Cancer 1998;34:1845-1851.

12 Carrim ZI, Murchison JT: The prevalence of simple renal and hepatic cysts detected by spiral computed tomography. Clin Radiol 2003;58:626-629.

13 Thomas KT, Welch D, Trueblood A, Sulur P, Wise P, Gorden DL, Chari RS, Wright JK Jr, Washington K, Pinson CW: Effective treatment of biliary cystadenoma. Ann Surg 2005;241:769-773.

14 The WHO classification of tumours of the digestive system; in Hamilton SR, Aaltonen LA (eds): Bile Duct Cystadenoma and Cystadenocarcinoma. Lyon, IARC Press, 2000.

N. Jawad and A.K. Woolf contributed equally to this report. 